\title{
Prevalence of deliberate self harm and attempted suicide within contemporary Goth youth subculture: longitudinal cohort study
}

Robert Young, Helen Sweeting, Patrick West

Public Health

Sciences Unit,

University of

Glasgow, Glasgow

G12 8RZ

Robert Young

research associate

Helen Sweeting

research scientist

Patrick West

senior research

scientist R Young robert@ msoc.mrc.gla.ac.uk

BMJ 2006;332:1058-61
MRC Social and

Correspondence to:

\begin{abstract}
Objective To investigate whether deliberate self harm is associated with contemporary Goth youth subculture.

Design Longitudinal cohort study.

Setting School and community based study of young people living in the Central Clydeside Conurbation, Scotland.

Participants 1258 people aged 19, surveyed in 2002-4 and followed-up since age 11 (1994).

Main outcome measures Lifetime prevalence of self harm and attempted suicide and their association with Goth youth subculture, before and after adjusting for confounders.

Results Identification as belonging to the Goth subculture was strongly associated with lifetime self harm and attempted suicide, with a prevalence of $53 \%$ and $47 \%$, respectively among the most highly identified group, and evidence for a dose-response relation. Adjusting for potential confounders did not significantly attenuate this association. Analysis of other youth subcultures showed that this effect was primarily associated with Goth subculture.

Conclusions Identification as belonging to the Goth subculture was the best predictor of self harm and attempted suicide. Although based on small numbers,
\end{abstract}

Table 1 Personal characteristics of 1258 youths by identification as belonging to the Goth youth subculture. Values are numbers (percentages) unless stated otherwise

\begin{tabular}{|c|c|c|c|c|}
\hline Characteristic & $\begin{array}{c}\text { None } \\
(\mathrm{n}=1165)^{*}\end{array}$ & $\begin{array}{c}\text { Just a bit } \\
(\mathrm{n}=37)\end{array}$ & $\begin{array}{l}\text { Quite a bit } \\
\qquad(\mathrm{n}=41)\end{array}$ & $\begin{array}{l}\text { Really heavily or } \\
\text { I am one ( } n=15)\end{array}$ \\
\hline \multicolumn{5}{|l|}{ Sex: } \\
\hline Male & $580(50)$ & $26(70)$ & $24(59)$ & $10(67)$ \\
\hline Female & $585(50)$ & $11(30)$ & $17(42)$ & $5(33)$ \\
\hline \multicolumn{5}{|l|}{ Social class: } \\
\hline Manual & $543(47)$ & $14(38)$ & $20(49)$ & 7 (47) \\
\hline Non-manual & $561(48)$ & $21(57)$ & $21(51)$ & $8(53)$ \\
\hline Unclassifiable & $61(5)$ & $2(5)$ & 0 & 0 \\
\hline \multicolumn{5}{|l|}{ Divorced or separated parents: } \\
\hline No & $963(83)$ & 34 (92) & $31(76)$ & $13(87)$ \\
\hline Yes & $202(17)$ & $3(8)$ & $10(24)$ & $2(13)$ \\
\hline \multicolumn{5}{|l|}{ Smoking: } \\
\hline Non-smoker & $832(72)$ & $22(60)$ & $28(68)$ & $8(53)$ \\
\hline Smoker (regular or occasional) & $332(29)$ & $15(41)$ & $13(32)$ & $7(47)$ \\
\hline \multicolumn{5}{|l|}{ Any drug use: } \\
\hline No & $527(45)$ & $14(38)$ & $16(39)$ & $2(13)$ \\
\hline Yes & $638(55)$ & $23(62)$ & $25(61)$ & $13(87)$ \\
\hline \multicolumn{5}{|l|}{ Alcohol use: } \\
\hline Never & $83(7)$ & $3(8)$ & $2(5)$ & 0 \\
\hline A few times a year & $213(18)$ & $6(16)$ & $8(20)$ & $5(33)$ \\
\hline Once a week & $327(28)$ & $9(24)$ & $13(32)$ & $2(13)$ \\
\hline Couple of times a week & $475(42)$ & $17(46)$ & $16(39)$ & $6(40)$ \\
\hline Every or most days & $67(6)$ & $2(5)$ & $2(5)$ & $2(13)$ \\
\hline Mean (SD) depression† & $19.01(4.1)$ & $19.18(4.5)$ & $19.88(4.2)$ & $20.44(4.4)$ \\
\hline
\end{tabular}

Denominators vary by up to seven cases owing to missing data.

*One participant who did not give identification is classed as "none" on basis of music preference.

tSeven cases omitted owing to missing data. additional longitudinal analysis suggests both selection and modelling mechanisms are involved, selection mechanisms possibly being more likely.

\section{Introduction}

Deliberate self harm is relatively common among young people, with rates of $7 \%-14 \%$ in the United Kingdom. ${ }^{2}$ Common acts of self harm include cutting, burning, and punching, usually resulting in relatively minor injury; rarer, more serious, acts include self poisoning.

Self harm is understood to be a maladaptive coping strategy intended to relieve negative emotions such as anger, anxiety, frustration, or guilt. It is usually unrelated to an immediate suicide attempt. Knowledge about risk factors is limited, but previous research has implicated peer modelling and depression. ${ }^{12}$ Self harm is related to later risk of suicide and psychiatric disorder and has a high prevalence among certain subpopulations, notably prisoners and homosexual and bisexual people. ${ }^{1-3}$ The media have linked contemporary Goth youth subculture with self harm, ${ }^{4}$ but evidence for this is sparse. "Goth" could be described as a subgenre of punk with a dark and sinister aesthetic, with aficionados conspicuous by their range of distinctive clothing and makeup and tastes in music. ${ }^{45}$ We investigated whether identification with Goth is associated with self harm.

\section{Methods}

We collected data on participants at age 19 through the west of Scotland 11-16 study, a longitudinal survey of health and lifestyles. ${ }^{6}{ }^{7}$ Respondents were recruited during their final year (1994) of primary school (age $11, \mathrm{n}=2586)$ and resurveyed at ages 13,15 , and 19 $(2002-4, n=1258)$. As weights to adjust for attrition bias did not alter the results we report unweighted data. For youths aged 15 and 19 we used a computerised version of the diagnostic interview schedule for children (Voice-DISC) ${ }^{6}$ to collect data on psychiatric diagnosis, including a question on suicide attempts.

At age 19, during the Voice-DISC, participants were asked "have you ever in your whole life, tried to kill yourself or make a suicide attempt?" One section of the survey interview asked "have you ever tried to hurt yourself or harm yourself deliberately," the methods used, and age at first act of self harm. Self harm was coded as any method and methods involving cutting, scratching, or scoring. In a separate section

$\mathrm{P+}$ Additional tables are on bmj.com


participants were also asked at what age and how much they identified (present and past) with a variety of youth subcultures, including Goth, on a five point scale. The two most extreme categories were collapsed and comprise the most highly identified group. We focus on current and lifetime peak (defined as highest current or past) identification.

We used logistic regression, with lifetime self harm and lifetime suicide attempt as outcomes, adjusted for sex, social class of head of household (coded, non-manual, manual, or unclassifiable according to the registrar general's schema of occupational social class), ${ }^{78}$ lifetime parental separation or divorce, substance use (smoking, any drug, alcohol), and the highest score on a depression scale administered at ages 11,13 , and $15 .{ }^{9}$

\section{Results}

Table 1 shows the characteristics of the sample according to level of Goth identification. No differences were found by social class, parental separation, rates of smoking, alcohol use, or previous depression, but males were more likely to identify with Goths (Pearson $\chi^{2}$ test, $8.582, \mathrm{df}=3, \mathrm{P}=0.035$ ), and rates of drug use were slightly higher among those who were most highly identified (Pearson $\chi^{2}$ test, 7.318, $\mathrm{df}=3, \mathrm{P}=0.062$ ).

Table 2 shows the results for lifetime rates of self harm (any method); self harm from cutting, scratching or scoring; and attempted suicide (rates for overall sample: $7.1 \%, 4.1 \%$, and $6.4 \%$ ). Lifetime self harm (any method) and lifetime suicide attempt were highly correlated $(r=0.59)$.

Table 2 Associations of deliberate self harm and suicide attempt with current Goth identification and other variables

\begin{tabular}{|c|c|c|c|c|c|c|c|c|c|}
\hline \multirow[b]{2}{*}{ Variable } & \multicolumn{3}{|c|}{$\begin{array}{l}\text { Lifetime deliberate self harm by any method } \\
\qquad(\mathrm{n}=1258)^{*} \dagger\end{array}$} & \multicolumn{3}{|c|}{$\begin{array}{l}\text { Lifetime deliberate self harm by cutting, } \\
\text { scratching, or scoring }(n=1258)^{\star} \dagger\end{array}$} & \multicolumn{3}{|c|}{ Lifetime suicide attempt ( $\mathrm{n}=1255) \dagger$} \\
\hline & $\begin{array}{l}\text { No (\%) who } \\
\text { self harm }\end{array}$ & $\begin{array}{l}\text { Unadjusted } \\
\text { odds ratio } \\
(95 \% \text { CI) }\end{array}$ & $\begin{array}{l}\text { Adjusted odds } \\
\text { ratio }(95 \% \mathrm{CI}) \ddagger\end{array}$ & $\begin{array}{l}\text { No (\%) who } \\
\text { self harm }\end{array}$ & $\begin{array}{l}\text { Unadjusted } \\
\text { odds ratio } \\
\text { (95\% CI) }\end{array}$ & $\begin{array}{l}\text { Adjusted odds } \\
\text { ratio }(95 \% \mathrm{CI}) \ddagger\end{array}$ & $\begin{array}{l}\text { No }(\%) \text { who } \\
\text { self harm }\end{array}$ & $\begin{array}{l}\text { Unadjusted } \\
\text { odds ratio } \\
(95 \% \mathrm{Cl})\end{array}$ & $\begin{array}{l}\text { Adjusted odds } \\
\text { ratio }(95 \% \mathrm{CI}) \ddagger\end{array}$ \\
\hline \multicolumn{10}{|l|}{$\begin{array}{l}\text { Current } \\
\text { identification§: }\end{array}$} \\
\hline None & $67 / 1165$ (6) & 1.00 & 1.00 & $36 / 1165$ (3) & 1.00 & 1.00 & $63 / 1162(5)$ & 1.00 & 1.00 \\
\hline Just a bit & $7 / 37$ (19) & $\begin{array}{c}3.82 \\
(1.62 \text { to } 9.03) \\
\end{array}$ & $\begin{array}{c}3.81 \\
(1.47 \text { to } 9.88) \\
\end{array}$ & $3 / 37(8)$ & $\begin{array}{c}2.77 \\
(0.81 \text { to } 9.43) \\
\end{array}$ & $\begin{array}{c}3.84 \\
(1.06 \text { to } 13.98) \\
\end{array}$ & $3 / 37$ (8) & $\begin{array}{c}1.54 \\
(0.46 \text { to } 5.15) \\
\end{array}$ & $\begin{array}{c}1.44 \\
(0.33 \text { to } 6.35) \\
\end{array}$ \\
\hline Quite a bit & $7 / 41$ & $\begin{array}{c}3.37 \\
(1.44 \text { to } 7.89)\end{array}$ & $\begin{array}{c}3.13 \\
(1.24 \text { to } 7.88)\end{array}$ & 6/41 (15) & $\begin{array}{c}5.38 \\
(2.13 \text { to } 13.59)\end{array}$ & $\begin{array}{c}5.55 \\
(1.97 \text { to } 15.67)\end{array}$ & $7 / 41$ & $\begin{array}{c}3.59 \\
(1.53 \text { to } 8.42)\end{array}$ & $\begin{array}{c}3.59 \\
(1.40 \text { to } 9.23)\end{array}$ \\
\hline $\begin{array}{l}\text { Really heavily } \\
\text { or I am one }\end{array}$ & $8 / 15(53)$ & $\begin{array}{c}18.73 \\
(6.59 \text { to } 53.20) \\
\end{array}$ & $\begin{array}{c}16.35 \\
(5.06 \text { to } 52.91) \\
\end{array}$ & $7 / 15(47)$ & $\begin{array}{c}27.44 \\
\text { (9.44 to } 79.78) \\
\end{array}$ & $\begin{array}{c}24.75 \\
\text { (6.91 to } 88.66) \\
\end{array}$ & $7 / 15(47)$ & $\begin{array}{c}15.26 \\
\text { (5.36 to } 43.43) \\
\end{array}$ & $\begin{array}{c}16.37 \\
(4.93 \text { to } 54.35) \\
\end{array}$ \\
\hline \multicolumn{10}{|l|}{ Sex: } \\
\hline Male & $37 / 640$ (6) & 1.00 & 1.00 & $17 / 640$ (3) & 1.00 & 1.00 & $25 / 639$ (4) & 1.00 & 1.00 \\
\hline Female & $52 / 618$ (8) & $\begin{array}{c}1.50 \\
(0.97 \text { to } 2.32)\end{array}$ & $\begin{array}{c}1.42 \\
(0.85 \text { to } 2.39)\end{array}$ & $35 / 618$ (6) & $\begin{array}{c}2.20 \\
(1.22 \text { to } 3.97)\end{array}$ & $\begin{array}{c}2.43 \\
(1.19 \text { to } 4.94)\end{array}$ & $55 / 616(4)$ & $\begin{array}{c}2.41 \\
(1.48 \text { to } 3.92)\end{array}$ & $\begin{array}{c}2.50 \\
(1.42 \text { to } 4.41)\end{array}$ \\
\hline \multicolumn{10}{|l|}{ Social class: } \\
\hline Manual & $39 / 584(7)$ & 1.00 & 1.00 & $20 / 584(3)$ & 1.00 & 1.00 & $40 / 582(7)$ & 1.00 & 1.00 \\
\hline Non-manual & $45 / 611(7)$ & $\begin{array}{c}1.20 \\
(0.46 \text { to } 3.18)\end{array}$ & $\begin{array}{c}1.28 \\
(0.78 \text { to } 2.08)\end{array}$ & $30 / 611$ (10) & $\begin{array}{c}0.92 \\
(0.21 \text { to } 4.05)\end{array}$ & $\begin{array}{c}1.15 \\
(0.25 \text { to } 5.40)\end{array}$ & $34 / 610(6)$ & $\begin{array}{c}0.80 \\
(0.50 \text { to } 1.28)\end{array}$ & $\begin{array}{c}1.18 \\
\text { (0.42 to } 3.29)\end{array}$ \\
\hline Unclassifiable & $5 / 63(8)$ & $\begin{array}{c}1.11 \\
(0.71 \text { to } 1.73) \\
\end{array}$ & $\begin{array}{c}1.10 \\
(0.36 \text { to } 3.38) \\
\end{array}$ & $2 / 63$ (3) & $\begin{array}{c}1.46 \\
(0.82 \text { to } 2.59) \\
\end{array}$ & $\begin{array}{c}1.63 \\
(0.85 \text { to } 3.10) \\
\end{array}$ & 6/63 (10) & $\begin{array}{c}1.43 \\
(0.58 \text { to } 3.51) \\
\end{array}$ & $\begin{array}{c}0.91 \\
(0.54 \text { to } 1.53)\end{array}$ \\
\hline \multicolumn{10}{|l|}{$\begin{array}{l}\text { Divorced or } \\
\text { separated } \\
\text { parents: }\end{array}$} \\
\hline No & $64 / 1041$ (6) & 1.00 & 1.00 & $38 / 1041$ (4) & 1.00 & 1.00 & $51 / 1039(5)$ & 1.00 & 1.00 \\
\hline Yes & $25 / 217$ (12) & $\begin{array}{c}1.99 \\
(1.22 \text { to } 3.24) \\
\end{array}$ & $\begin{array}{c}1.74 \\
\text { (1.01 to } 3.02) \\
\end{array}$ & $14 / 217(7)$ & $\begin{array}{c}1.82 \\
(0.97 \text { to } 3.42) \\
\end{array}$ & $\begin{array}{c}1.46 \\
(0.70 \text { to } 3.06) \\
\end{array}$ & $29 / 216(13)$ & $\begin{array}{c}3.00 \\
\text { (1.86 to } 4.86) \\
\end{array}$ & $\begin{array}{c}2.45 \\
\text { (1.43 to } 4.20) \\
\end{array}$ \\
\hline \multicolumn{10}{|l|}{ Smoking: } \\
\hline Non-smoker & $38 / 890(4)$ & 1.00 & 1.00 & $23 / 890(3)$ & 1.00 & 1.00 & $36 / 887 \quad(4)$ & 1.00 & 1.00 \\
\hline $\begin{array}{l}\text { Smoker } \\
\text { (regular, } \\
\text { occasional) }\end{array}$ & $51 / 367 \quad(14)$ & $\begin{array}{c}3.62 \\
(2.33 \text { to } 5.62)\end{array}$ & $\begin{array}{c}2.45 \\
(1.47 \text { to } 4.07)\end{array}$ & $29 / 367$ & $\begin{array}{c}3.23 \\
\text { (1.84 to } 5.67)\end{array}$ & $\begin{array}{c}1.82 \\
(0.95 \text { to } 3.51)\end{array}$ & 44/367 (12) & $\begin{array}{c}3.22 \\
(2.04 \text { to } 5.09)\end{array}$ & $\begin{array}{c}1.93 \\
(1.13 \text { to } 3.29)\end{array}$ \\
\hline \multicolumn{10}{|l|}{ Any drug use: } \\
\hline No & 19/699 (3) & 1.00 & 1.00 & 7/699 (1) & 1.00 & 1.00 & 18/698 (3) & 1.00 & 1.00 \\
\hline Yes & $70 / 559$ (10) & $\begin{array}{c}3.16 \\
(1.88 \text { to } 5.32) \\
\end{array}$ & $\begin{array}{c}2.04 \\
(1.11 \text { to } 3.76) \\
\end{array}$ & $45 / 559(6)$ & $\begin{array}{c}5.43 \\
\text { (2.43 to 12.13) } \\
\end{array}$ & $\begin{array}{c}3.71 \\
(1.50 \text { to } 9.17) \\
\end{array}$ & $62 / 557$ (9) & $\begin{array}{c}2.92 \\
(1.71 \text { to } 5.00) \\
\end{array}$ & $\begin{array}{c}2.11 \\
(1.12 \text { to } 3.98) \\
\end{array}$ \\
\hline \multicolumn{10}{|l|}{ Alcohol use: } \\
\hline Never & $5 / 88 \quad(6)$ & 1.00 & 1.00 & $3 / 88$ (3) & 1.00 & 1.00 & $5 / 87 \quad(6)$ & 1.00 & 1.00 \\
\hline $\begin{array}{l}\text { Few times a } \\
\text { year }\end{array}$ & 19/232 (8) & $\begin{array}{c}1.48 \\
(0.54 \text { to } 4.10)\end{array}$ & $\begin{array}{c}1.15 \\
\text { (0.39 to } 3.43)\end{array}$ & $10 / 232$ & $\begin{array}{c}1.28 \\
(0.34 \text { to } 4.75)\end{array}$ & $\begin{array}{c}0.79 \\
(0.19 \text { to } 3.30)\end{array}$ & 18/231 (8) & $\begin{array}{c}1.39 \\
(0.50 \text { to } 3.86)\end{array}$ & $\begin{array}{c}0.81 \\
\text { (0.27 to } 2.44)\end{array}$ \\
\hline Once a week & $18 / 351$ & $\begin{array}{c}0.90 \\
(0.32 \text { to } 2.49) \\
\end{array}$ & $\begin{array}{c}0.75 \\
(0.25 \text { to } 2.22) \\
\end{array}$ & $9 / 351 \quad(3)$ & $\begin{array}{c}0.75 \\
(0.20 \text { to } 2.81) \\
\end{array}$ & $\begin{array}{c}0.52 \\
(0.12 \text { to } 2.17) \\
\end{array}$ & $17 / 350$ (9) & $\begin{array}{c}0.84 \\
(0.30 \text { to } 2.34) \\
\end{array}$ & $\begin{array}{c}0.55 \\
(0.18 \text { to } 1.64) \\
\end{array}$ \\
\hline $\begin{array}{l}\text { Couple of times } \\
\text { a week }\end{array}$ & $40 / 514$ (8) & $\begin{array}{c}1.40 \\
(0.54 \text { to } 3.65) \\
\end{array}$ & $\begin{array}{c}1.11 \\
\text { (0.39 to } 3.13) \\
\end{array}$ & $25 / 514$ & $\begin{array}{c}1.45 \\
(0.43 \text { to } 4.90) \\
\end{array}$ & $\begin{array}{c}0.99 \\
(0.26 \text { to } 3.81) \\
\end{array}$ & $33 / 514$ (6) & $\begin{array}{c}1.13 \\
(0.43 \text { to } 2.97) \\
\end{array}$ & $\begin{array}{c}0.77 \\
\text { (0.27 to } 2.21 \text { ) }\end{array}$ \\
\hline $\begin{array}{l}\text { Every or most } \\
\text { days }\end{array}$ & $7 / 73$ (10) & $\begin{array}{c}1.76 \\
(0.53 \text { to } 5.80) \\
\end{array}$ & $\begin{array}{c}1.05 \\
(0.28 \text { to } 4.00)\end{array}$ & $5 / 73 \quad(7)$ & $\begin{array}{c}2.08 \\
(0.48 \text { to } 9.03) \\
\end{array}$ & $\begin{array}{c}1.41 \\
(0.28 \text { to } 7.14) \\
\end{array}$ & $7 / 73$ (10) & $\begin{array}{c}1.74 \\
\text { (0.53 to } 5.73) \\
\end{array}$ & $\begin{array}{c}1.06 \\
\text { (0.28 to } 4.06)\end{array}$ \\
\hline $\begin{array}{l}\text { Mean (SD) } \\
\text { depression }\end{array}$ & $19.06(4.1)$ & $\begin{array}{c}1.15 \\
(1.09 \text { to } 1.21)\end{array}$ & $\begin{array}{c}1.13 \\
(1.07 \text { to } 1.20)\end{array}$ & $19.06(4.1)$ & $\begin{array}{c}1.18 \\
(1.11 \text { to } 1.26)\end{array}$ & $\begin{array}{c}1.16 \\
(1.08 \text { to } 1.25)\end{array}$ & $19.06(4.1)$ & $\begin{array}{c}1.12 \\
(1.07 \text { to } 1.18)\end{array}$ & $\begin{array}{c}1.08 \\
(1.02 \text { to } 1.15)\end{array}$ \\
\hline
\end{tabular}

${ }^{*}$ Age participants first began to self harm: mean (SD) 15.6 (2.3) years (range 8-19 years).

†20 participants self harmed in past year, two attempted suicide in past month.

$\ddagger$ Seven cases omitted in adjusted model owing to missing data.

§one participant who did not give identification is classed as "none" on basis of music preference. 
Table 3 Association of lifetime deliberate self harm by any method, with current subculture identification before and after adjusting for Goth identification. Values are adjusted odds ratios (95\% confidence intervals) unless stated otherwise

\begin{tabular}{|c|c|c|c|c|}
\hline \multirow{2}{*}{$\begin{array}{l}\text { Current identification } \\
\text { (heavy or I am } \\
\text { one)t‡ }\end{array}$} & \multirow{2}{*}{$\begin{array}{l}\text { No (\%) who self } \\
\text { harm }\end{array}$} & \multirow{2}{*}{$\begin{array}{c}\text { Model } 1(\mathrm{n}=1258)^{*} \\
\begin{array}{c}\text { According to subcultural } \\
\text { identification }\end{array}\end{array}$} & \multicolumn{2}{|c|}{ Model $2(n=1258)^{*}$} \\
\hline & & & $\begin{array}{l}\text { According to subcultural } \\
\text { identification§ }\end{array}$ & According to Goth identification? \\
\hline Goth & $8 / 15(53)$ & 14.16 (4.42 to 45.39$)$ & - & - \\
\hline Punk & $4 / 17$ (24.5) & 4.42 (1.28 to 15.33$)$ & 2.08 (0.50 to 8.61$)$ & 9.84 (2.77 to 34.97$)$ \\
\hline Heavy metal & $9 / 48(19)$ & 3.58 (1.51 to 8.51$)$ & 1.90 (0.68 to 5.33$)$ & 12.00 (3.55 to 40.56) \\
\hline Mosher & $4 / 24(17)$ & 3.49 (1.08 to 11.27$)$ & 1.75 (0.45 to 6.83$)$ & 13.31 (4.05 to 43.74) \\
\hline Nu-metal & $2 / 12(17)$ & 3.04 (0.57 to 16.06$)$ & 1.56 (0.25 to 9.78$)$ & 14.86 (4.62 to 47.78$)$ \\
\hline Skater & $3 / 16(19)$ & 2.79 (0.71 to 10.93$)$ & $3.26(0.83$ to 12.80$)$ & 13.46 (4.15 to 43.62$)$ \\
\hline Grunge & $3 / 24(13)$ & 2.07 (0.57 to 7.56$)$ & $1.49(0.37$ to 6.04$)$ & 13.81 (4.30 to 44.37$)$ \\
\hline Retro & 10/101 (10) & 1.34 (0.64 to 2.81$)$ & 1.24 (0.58 to 2.66$)$ & 16.03 (4.81 to 53.44$)$ \\
\hline Indie & $4 / 104 \quad(0.3)$ & 0.49 (0.17 to 1.42$)$ & $0.42(0.14$ to 1.26$)$ & 14.39 (4.48 to 46.21$)$ \\
\hline Rave & $3 / 27(11)$ & 1.39 (0.39 to 4.93$)$ & 1.54 (0.43 to 5.49$)$ & 14.40 (4.49 to 46.15$)$ \\
\hline Club & 14/127 (11) & 1.40 (0.74 to 2.67$)$ & 1.47 (0.77 to 2.80) & 12.37 (3.79 to 40.38) \\
\hline Garage & $4 / 16(25)$ & 4.31 (1.18 to 15.71$)$ & $2.90(0.71$ to 11.76$)$ & 14.17 (4.42 to 45.43) \\
\hline Hip-hop & $7 / 97(17)$ & 1.04 (0.45 to 2.40$)$ & 0.96 (0.40 to 2.32$)$ & 14.15 (4.41 to 45.41$)$ \\
\hline Pop & $11 / 159(7)$ & 0.88 (0.44 to 1.78$)$ & 0.91 (0.45 to 1.83$)$ & 14.59 (4.55 to 46.75) \\
\hline Other & $5 / 33(15)$ & 1.69 (0.59 to 4.85$)$ & 1.89 (0.66 to 5.43$)$ & 20.92 (5.93 to 73.85 ) \\
\hline
\end{tabular}

${ }^{*}$ Adjusted for sex, social class, divorced or separated parents, smoking, ever use of drugs, alcohol use, and depression.

tDichotomisation of subcultural identity was implemented solely to simplify and condense results. Analyses carried out using previous four point identity scale produced virtually identical results.

$\ddagger$ Because of extremely low ( $\leq 10$ cases) frequencies, several youth subcultures were excluded (skinhead, breakers, mods, hippy)

$\S$ After adjusting for Goth identification.

ๆAfter adjusting for subcultural identification

Current Goth identification was strongly associated with lifetime prevalence of self harm and attempted suicide, with a prevalence of $53 \%$ for self harm (any method); $47 \%$ for self harm involving cutting, scratching, or scoring; and $47 \%$ for lifetime suicide attempt among the most highly identified, and evidence suggesting a dose-response relation. Predictors of self harm and suicide attempt were being female, having divorced or separated parents, smoking and any drug (not alcohol) use, and prior depression. Adjusting for these factors did not attenuate the Goth identification effect, which remained the single strongest predictor of either self harm or suicide attempt (table 2). Lifetime identification produced similar results (see table $\mathrm{A}$ on bmj.com).

Of 25 participants with a high identification (at some point in their lifetime) with the Goth subculture, 12 had harmed themselves; five before identification as Goth, two after, and four at about the same time (one participant had poor recall).

To determine how specific this identification effect was to Goth, as opposed to a general effect attributable to any other subculture, we carried out a series of additional analyses substituting Goth identification with 14 other common youth subcultures (table 3). Model 1 shows the association (odds) between each of the subcultures (dichotomised as "heavy" or "I am one," compared with "none," "just," or "quite a bit") and lifetime self harm, after adjusting for confounders. Although some other subcultures were also associated with self harm (Punk, odds ratio 4.42, 95\% confidence interval 1.28 to 15.33 ; Mosher, $3.49,1.08$ to 11.27 ), the association was strongest for Goth $(14.16,4.42$ to 45.39). Goth identification remained the only subculture which significantly predicted self harm after adjusting for other subcultures (model 2, table 3). Results were similar for self harm involving cutting, scratching, or scoring and for lifetime suicide attempt (see tables B and C on bmj.com).

\section{Discussion}

Identification by youth aged 19 as belonging to the Goth subculture was the best predictor of self harm and suicide attempt. This effect was not attenuated by adjusting for identification with any other youth subculture. Self harm could be a normative component of Goth subculture including emulation of subcultural icons or peers who self harm (modelling mechanisms). Alternatively, it could be explained by selection, with young people with a particular propensity to self harm being attracted to the subculture.

Although our study is based on small numbers, our data suggest that both processes are involved, with selection mechanisms possibly being more likely. Replication in alternative locations is needed to determine if this is widespread or localised, and a persistent or transient phenomenon.

We thank Michael Van Beinum for help in formulating questions on self harm in adolescence, Chris Lucas for providing the Voice-DISC and software support, and Sally

\section{What is already known on this topic}

Deliberate self harm is common among young people

It has a high prevalence in certain subpopulations and may be associated with depression, attempted suicide, and various psychiatric diagnoses later in life

\section{What this study adds}

The prevalence of both lifetime deliberate self harm and attempted suicide is high within Goth youth subculture

The causal mechanism remains unclear 
Macintyre and Paul Hodkinson for commenting on draft manuscripts.

Contributors: All authors contributed to the design and writing up of the study. RY carried out the analysis and is guarantor.

Funding: All authors are supported financially by the Medical Research Council of Great Britain.

Competing interests: None declared.

Ethical approval: Glasgow University ethics committee.

1 Hawton K, James A. ABC of adolescence: suicide and deliberate self harm in young people. BMJ 2005;330:891-4.

Skegg K. Self-harm. Lancet 2005;28:1471-83.

3 Skegg K, Nada-Raja S, Dickson N, Paul C, Williams S. Sexual orientation and self-harm in men and women. Am J Psychiatry 2003;160:541-6.
4 Beyond the pale. Radio 1 2002; 2 Nov. www.bbc.co.uk/radio1/alt/ stevelamacq/documentaries/beyond the pale20021104.shtml (accessed 7 Jul 2005).

Hodkinson P. Goth: identity, style and subculture. Oxford: Berg, 2002.

6 West P, Sweeting H, Der G, Barton J, Lucas C. Voice-DISC identified DSM-IV disorders among 15-year-olds in the west of Scotland.J Am Acad Child Adolesc Psychiatry 2003;42:941-9.

7 West $\mathrm{P}$, Sweeting $\mathrm{H}$, Speed E. We really do know what you do: a comparison of reports from 11 year olds and their parents in respect of parental economic activity and occupation. Sociology 2001:35:539-59.

8 Office of Population Census and Surveys. Standard occupational classification. London: HMSO, 1991.

9 Kandel D, Davies M. Epidemiology of depressive mood in adolescents. Arch Gen Psychiatry 1982;29:1205-12.

(Accepted 15 February 2006)

doi $10.1136 /$ bmj.38790.495544.7C

\title{
Origin and funding of the most frequently cited papers in medicine: database analysis
}

\author{
Nikolaos A Patsopoulos, Apostolos A Analatos, John P A Ioannidis
}

\begin{abstract}
Objective To evaluate changes in the role of academics and the sources of funding for the medical research cited most frequently over the past decade.

Design Database analysis.

Data sources Web of Knowledge database.

Methods For each year from 1994 to 2003, articles in the domain of clinical medicine that had been cited most often by the end of 2004 were identified. Changes in author's affiliations and funding sources were evaluated.

Results Of the 289 frequently cited articles, most had at least one author with a university $(76 \%)$ or hospital $(57 \%)$ affiliation, and the proportion of articles with each type of affiliation was constant over time. Government or public funding was most common (60\% of articles), followed by industry (36\%). The proportion of most frequently cited articles funded by industry increased over time (odds ratio 1.17 per year, $\mathrm{P}=0.001$ ) and was equal to the proportion funded by government or public sources by 2001.65 of the 77 most cited randomised controlled trials received funding from industry, and the proportion increased significantly over time (odds ratio 1.59 per year, $\mathrm{P}=0.003)$. 18 of the 32 most cited trials published after 1999 were funded by industry alone.

Conclusion Academic affiliations remain prominent among the authors of the most frequently cited medical research. Such research is increasingly funded by industry, often exclusively so. Academics may be losing control of the clinical research agenda.
\end{abstract}

\section{Introduction}

Medical research may depend on funding from the private sector, in particular from biotechnology and drug companies. ${ }^{12}$ This funding may lead to conflicts of interest about the results of medical research..$^{1-5}$ Despite the importance of this issue, no quantitative evidence is available on the contribution of academics and the funding of studies, and how these might have changed during the past decade. We analysed the affiliations of authors and the funding sources of articles from clinical medicine that had received the highest number of citations according to the essential science indicators module of the Web of Knowledge database. Citations do not reflect fully the quality of a paper, but they are a measure of the impact of research. ${ }^{6}$ Our aim was to see whether the impact of academic institutions and the drug industry has changed during the past decade.

\section{Methods}

Identification of the most frequently cited papers We downloaded the most frequently cited papers in clinical medicine between 1994 and 2004 from the essential science indicators module of the Web of Knowledge produced by the Institute for Scientific Information (ISI). Each paper had been cited more than 325 times. Articles were ranked according to how many times they were cited by any journal indexed by ISI between 1 January 1994 and 31 December 2004 . Clinical medicine is one of 21 scientific domains catalogued by ISI and covers all medical sciences and subspecialties.

We screened 1846 articles and retained the 30 most cited articles from each year. We analysed papers from 2002-4 together (23 articles from 2002 and seven from 2003; no article published in 2004 had been cited more than 325 times by the end of the year).

Essential science indicators may have failed to classify a few earlier articles with group authorship, usually intervention studies and meta-analyses. ${ }^{7}$ Therefore, we also performed a more detailed screen of the New England Journal of Medicine, JAMA, Lancet, and BMJ. This detailed search yielded another 19 articles. We analysed 289 articles in total (see appendix on bmj.com).

\section{Data extraction}

From the full text versions of the 289 articles we extracted data on the journal, year of publication, type

\section{An appendix with the 289 most frequently cited articles is on} bmj.com
Department of Hygiene and Epidemiology, University of Ioannina School of Medicine, Ioannina, Greece

Greece

Nikolaos A
Patsopoulos research associate John P A Ioannidis professor

University of Thessaly School of Medicine, Larissa, Greece

Apostolos A Analato medical student

Correspondence to: $\mathrm{J}$ P A Ioannidis jioannid@cc.uoi.gr

BMJ 2006;332:1061-4 